BEATA SZABAŁA

Uniwersytet Marii Curie-Skłodowskiej

$w$ Lublinie

\title{
ZASOBY OSOBISTE A NIEPEŁNOSPRAWNOŚĆ SENSORYCZNA
}

\begin{abstract}
Szabała Beata, Zasoby osobiste a niepetnosprawność sensoryczna [Personal Resources and Sensoric Disability]. Studia Edukacyjne nr 43, 2017, Poznań 2017, pp. 223-245. Adam Mickiewicz University Press. ISSN 1233-6688. DOI: 10.14746/ se.2017.43.14

Personal resources are an important factor contributing to health and the quality of life. Their role is even greater in difficult situations, such as the ones experienced by individuals with visual and auditory impairments/deficits. The research was to diagnise personal resources of adults with isual and auditory impairments/deficits. These resources were analysed in terms of the meanig of life, self-assessment, and social support. Research was conducted with 80 respondents aged 20-30, where 40 respondents were visually impaired, and 40 respondents were auditorily impaired. Instruments used: The Meanig of Life Scale by J.C. Crumbaugh and K.T. Maholicka, A Questionnaire of Social Support by J.S. Norbeck, a Self-Assessment Scale by W.H. Fitts, and author's own questionnarie. Research findings reveal certain divergences between groups in terms of the analysed resources, with the most significant ones in the sphere of self-assessment.
\end{abstract}

Key words: personal resources, individuals with visual impairment, individuals with auditory impairment

\section{Wprowadzenie}

W literaturze przedmiotu wiele uwagi poświęca się problematyce zasobów osobistych, upatrując w nich czynniki sprzyjające zdrowiu. Pojęcie zasobów osobistych stosowane jest $\mathrm{w}$ odniesieniu do tych zmiennych, które pomagają w radzeniu sobie ze stresem ${ }^{1}$. R.H. Moos i J.A. Scheafer ${ }^{2}$ określają osobiste zasoby radzenia sobie jako relatywnie stałe dyspozycyjne cechy

${ }^{1}$ R. Poprawa, Zasoby osobiste w radzeniu sobie ze stresem, [w:] Podstawy psychologii zdrowia, red. G. Dolińska-Zygmunt, Wrocław 2001, s. 106.

2 R.H. Moos, J.A. Schaefer, Coping resources and process: current concepts and measures, [w:] Handbook of stress: theoretical and clinical aspects, red. L. Goldberger, S. Breznits, New York 1993, s. 238. 
człowieka, które wpływają na przebieg i rezultat procesów oceny poznawczej stresu oraz radzenia sobie i zwrotnie mogą być zmieniane przez skumulowane rezultaty tych procesów. Do ważnych zasobów zalicza się m.in. wsparcie społeczne, poczucie własnej wartości, poczucie własnej skuteczności, poczucie koherencji, optymizm, nadzieję, poczucie umiejscowienia kontroli, równowagę emocjonalną, kompetencje społeczne, wiarę $\mathrm{w}$ moce nadprzyrodzone, uzdolnienia, poczucie sensu życia, poczucie humoru, wiedzę, inteligencję ${ }^{3}$.

Posiadanie wielu zasobów jest jednym z warunków efektywnego funkcjonowania człowieka, $\mathrm{w}$ tym także radzenia sobie ze stresem. Zasoby mogą funkcjonować przed zadziałaniem stresora, jak i po jego pojawieniu się. Oznacza to, że mogą być w stosunku do stresu proaktywne i reaktywne4.

Istnieją różnice pomiędzy ludźmi w zakresie zasobów wykorzystywanych $w$ sytuacjach trudnych. Bogatsze zasoby warunkują efektywniejsze radzenie sobie ze stresem. W związku z tym ludzie nastawieni proaktywnie dążą do budowania zasobów zapewniających wysoką jakość funkcjonowania. Proaktywne kreowanie wyższego poziomu kompetencji i osiągnięć może być doświadczane jako możliwość znalezienia życiowego celu czy też uchwycenia sensu życia 5 .

Analizie zostaną poddane tutaj wybrane zasoby osobiste o szczególnym znaczeniu $\mathrm{w}$ optymalizowaniu psychospołecznego funkcjonowania człowieka, w tym także obciążonego niepełnosprawnością wzrokową czy słuchową, to jest poczucie sensu życia, wsparcie społeczne, samoocena.

Zdaniem V. Frankla ${ }^{6}$, poczucie sensu życia jest stanem podmiotowej satysfakcji jednostki, związanym z działaniem celowym i ukierunkowanym na wartości. Jest metapotrzebą determinującą rozwój osobowości i zdrowie psychiczne człowieka, której niezaspokojenie prowadzi do frustracji egzystencjalnej, rozumianej jako poczucie ogarniającej pustki i ograniczenie życiowej perspektywy. M.F. Steger7 określa poczucie sensu życia jako „stopień, w jakim ludzie rozumieją własne życie, tworzą sens i spostrzegają znaczenie

${ }^{3}$ R. Poprawa, Zasoby osobiste, s. 107-111; S. Hobfoll, Stres, kultura i społeczność. Psychologia i filozofia stresu, Gdańsk 2006, s. 73-74; N. Ogińska-Bulik, M. Kaflik-Piróg, Stres zawodowy w stużbach ratowniczych, Łódź 2006, s. 83-102.

${ }^{4} \mathrm{H}$. Sęk, Wsparcie spoteczne jako kategoria zasobów i wieloznaczne funkcje wsparcia, [w:] Zasoby osobiste i społeczne sprzyjające zdrowiu jednostki, red. Z. Juczyński, N. Ogińska-Bulik, Łódź 2003, s. 19.

${ }^{5}$ R. Schwarzer, S. Taubert, za: M. Brzezińska, Proaktywna starość. Strategie radzenia sobie ze stresem w okresie późnej dorostości, Warszawa 2011, s. 95.

${ }^{6}$ Za: S. Głaz, Sens życia, Kraków 1998, s. 29.

7 M.F. Steger, Meaning in life, [w:] The Oxford handbook of positive psychology, red. S.J. Lopez, C.R. Snyder, Oxford 2011, p. 682. 
w swoim życiu, wraz z jednoczesnym przekonaniem posiadania życiowych celów" ${ }^{\prime \prime}$. W ujęciu autora, poczucie sensu życia obejmuje dwa wymiary, tj. obecność i poszukiwanie. Pierwszy oznacza, że życie ma wyraźny sens i cel oraz wskazuje na znajomość tego, co czyni życie bardziej sensowne. Wymiar drugi reprezentuje stan dążenia do znaczących, ważnych i sensownych elementów życia. Zgodnie z powyższym, osoby mogą mieć sens życia, jak również mogą zmierzać do jego osiągnięcia.

Poczucie sensu życia wiąże się z głębokim przekonaniem o sensowności własnego życia. Źródłem takiego poczucia jest głębokie doświadczenie sensu w konkretnych sytuacjach życiowych, w szerokiej gamie działań, przeżywanych wyborów i podejmowanych decyzji ${ }^{9}$. Są to m.in. serdeczne kontakty z innymi, świadomość bycia potrzebnym, poszukiwanie i odkrywanie prawdy, praca zawodowa, działalność w sferze politycznej, działalność twórcza ${ }^{10}$. Poczucie sensu jest zatem bardzo mocno wbudowane w życie, w ludzki świat potrzeb, obserwacji, wszelkich dążeń, czy aktywności. Każdy człowiek ma potrzebę sensu, przez którą realizuje się ${ }^{11}$. Sens życia dotyczy poszczególnych etapów rozwoju człowieka, jego sytuacji życiowej12.

Sens życia nie jest dany, trzeba go nieustannie poszukiwać. Poszukiwanie to okupione jest niejednokrotnie wielkim trudem i wysiłkiem, gdyż wiąże się z koniecznością pokonywania niepewności i wątpienia. Trud szukania sensu własnego życia uzależniony jest od wielu czynników. Wśród nich wymienia się m.in. osobowość, inteligencję, środowisko, sposoby radzenia sobie w sytuacjach trudnych, przeżywane kryzysy osobiste. Niektórzy ludzie mają wiele problemów ze znalezieniem sensu życia. Zdarza się również, że odkryty sens życia podawany jest w wątpliwość i przestaje spełniać oczekiwania człowieka w sytuacjach kryzysu, zwłaszcza w tych, które można określić mianem kryzysu sensu życia. Pojawia się wówczas poczucie bezsensu życia ${ }^{13}$, które bardzo często przyczynia się do nerwicy, zaburzeń osobowości, utraty nadziei, zaufania, dążenia do wartości oraz posiadania

8 Tamże.

${ }^{9}$ K. Popielski, Psychologiczno-egzystencjalna interpretacja problematyki sensu i sensowności, [w:] Człowiek - wartości - sens, red. K. Popielski, Lublin 1996, s. 49-50.

${ }_{10}$ V. Frankl, za: J. Michalski, Konstruowanie tożsamości podmiotowej w kontekście kategorii sensu w pedagogice, Paedagogia Christiana, 2013, 2/32, s. 13.

${ }^{11}$ K. Popielski, Psychologiczno-egzystencjalna interpretacja problematyki sensu, s. 49-50.

12 J. Lulek, S. Głaz, Problematyka sensu ludzkiego życia, [w:] Człowiek i jego życie religijne, red. S. Głaz, Kraków 2009, s. 15.

${ }^{13}$ Z. Płużek, Osobowościowe uwarunkowania pytania o sens życia, [w:] Człowiek - wartości sens, s. 366. 
celów. Brak poczucia sensu życia manifestuje się w postaci uogólnionego smutku, frustracji, zniechęcenia, rozpaczy, co w konsekwencji może doprowadzić do różnorodnych uzależnień, a nawet podejmowania prób samobójczych $^{14}$.

Z powyższych informacji należy wnioskować, że poczucie sensu życia odgrywa istotną rolę w psychicznym funkcjonowaniu ludzi. Dzięki niemu człowiek może rozwijać swoje siły twórcze, siłę woli, zdolności do czerpania z własnych wewnętrznych zasobów oraz wyrażania siebie i kierowania się szczerymi uczuciami wobec innych ${ }^{15}$. Poczucie sensu życia jest silnym czynnikiem motywacyjnym do podejmowanych działań ${ }^{16}$, który wiąże się pozytywnie z dojrzałością w zakresie rozwoju osobistego, społecznego, dobrostanem psychicznym ${ }^{17}$ oraz religijnością ${ }^{18}$.

Osoby z niepełnosprawnością często zadają sobie pytania dotyczące sensu ich cierpienia, jak i sensu życia. Udzielenie odpowiedzi na te pytania nabiera dużego znaczenia, gdyż może być ważnym elementem kształtującym drogę ich dalszego rozwoju, co bezpośrednio wiąże się z zaakceptowaniem posiadanej niepełnosprawności, a nawet ocaleniem życia ${ }^{19}$. Wprawdzie pytania egzystencjalne formułowane przez osoby niepełnosprawne nie różnią się treściowo od formułowanych przez osoby pełnosprawne, ale częściej dotyczą niesprawiedliwości losu i niezawinionego poczucia cierpienia ${ }^{20}$. Pomimo to próby empirycznego określenia poczucia sensu życia osób z niepełnosprawnością nie prowadzą do jednoznacznych wyników. Niektóre badania ujawniają, iż osoby niepełnosprawne, w porównaniu z osobami pełnosprawnymi, cechuje niższy poziom poczucia sensu życia21, inne wska-

14 K. Popielski, Noetyczny wymiar osobowości. Psychologiczna analiza poczucia sensu życia, Lublin 1994, s. 208.

${ }^{15}$ S. Głaz, Sens życia, s. 36 .

${ }^{16}$ V. Frankl, za: R. Klamut, Typy struktury sensu życia a treści celów wybieranych do realizacji, Roczniki Psychologiczne, 2012, 4(15), s. 139.

${ }^{17}$ M.F. Steger, S. Oishi, T.B. Kashdan, Meaning in life across the life span: levels and correlates of meaning in life from emerging adulthood to older adulthood, The Journal of Positive Psychology, 2009, 4(1), s. 48.

${ }^{18} \mathrm{D}$. Krok, Religijny system znaczeń i religijne radzenie sobie ze stresem a eudajmonistyczny dobrostan psychiczny, Roczniki Psychologiczne/Annales of Psychology, 2014, 17(4), s. 661.

19 J.J. Karmiński, za: E.J. Konieczna, Poczucie sensu życia osób niepetnosprawnych ruchowo, Kraków 2010, s. 7.

${ }^{20}$ M. Gołaszewska, Estetyka wobec pytań egzystencjalnych. Funkcje piękna w życiu młodzieży niepetnosprawnej, [w:] Wymiary piękna, red. M. Gołaszewska, Kraków 1998, s. 131.

${ }^{21}$ M. Rorat, Rola poczucia sensu życia w zmaganiu się z niepetnosprawnościa ruchowa, Student Niepełnosprawny. Szkice i Rozprawy, 2000, 4, s. 100. 
zują brak znaczących różnic pomiędzy osobami niepełnosprawnymi i pełnosprawnymi w zakresie doświadczania sensu życia ${ }^{22}$.

Ważnym zasobem osobistym jest także wsparcie społeczne, które stanowi jeden z czynników odgrywających istotną rolę w utrzymaniu dobrego samopoczucia w ciągu życia. Samo pojęcie wsparcia cechuje się wieloznacznością, a próby jego doprecyzowania przyjmują różną postać. Określa się je m.in. jako rodzaj interakcji społecznej podjętej w sytuacji trudnej, problemowej zorientowanej na jej rozwiązanie, w obrębie której dokonuje się wymiana emocji, informacji, instrumentów działania, dóbr materialnych; jako dostępność relacji, dzięki, którym są zaspokajane interpersonalne potrzeby człowieka23; oraz jako stopień zakorzeniania społecznego, zobowiązania i bliskości24. Na złożoność zjawiska, jakim jest wsparcie społeczne, wskazują także cechujące je właściwości. W literaturze przedmiotu zwraca się uwagę na strukturalne i funkcjonalne właściwości wsparcia, które powinny być traktowane komplementarnie. Wsparcie społeczne z perspektywy strukturalnej utożsamiane jest $\mathrm{z}$ obiektywnie istniejącą siecią osób uznawanych przez jednostkę jako pełniących funkcję pomocną w sytuacjach trudnych. Wsparcie społeczne $\mathrm{z}$ perspektywy funkcjonalnej wyraża się natomiast w jego spodziewanych konsekwencjach na płaszczyźnie emocjonalnej, informacyjnej, instrumentalnej, materialnej, czy duchowej25. Analizując znaczenie wsparcia społecznego, należy uwzględnić wsparcie spostrzegane i otrzymywane. Wsparcie spostrzegane odnosi się do aktualnych przekonań na temat dostępności różnych form pomocy w sytuacji, gdyby okazała się ona niezbędna ${ }^{26}$. Natomiast, wsparcie otrzymywane dotyczy różnych form pomocy, które mają miejsce $\mathrm{w}$ trakcie interpersonalnej transakcji lub wymiany ${ }^{27}$. Większość badań zwraca jednak uwagę na wsparcie spostrzegane, które $\mathrm{w}$ porównaniu ze wsparciem otrzymywanym jest lepszym predykto-

${ }^{22}$ L. Bobowkicz-Lewartowska, Poczucie sensu życia jako wskaźnik psychicznego dobrostanu u osób z zaburzeniami widzenia, [w:] Wspótczesne problemy pedagogiki specjalnej, red. U. Bartnikowska, Cz. Kosakowski, A. Krause, Olsztyn 2008, s. 240.

${ }^{23}$ H. Sęk, R. Cieślak, Wsparcie społeczne - sposoby definiowania, rodzaje i źródta wsparcia, wybrane koncepcje teoretyczne, [w:] Wsparcie społeczne, stres i zdrowie, red. H. Sęk, R. Cieślak, Warszawa 2005, s. 18.

24 N. Knoll, R. Schwarzer, Prawdziwych przyjaciót... Wsparcie społeczne, stres, choroba i śmierć, [w:] Tamże, s. 33.

${ }^{25}$ H. Sęk, R. Cieślak, Wsparcie społeczne - sposoby definiowania, s. 15.

${ }^{26}$ R. Schwarzer, N. Knoll, Functional roles of social support within the stress and coping process: a theoretical and empirical overview, International Journal of Psychology, 2007, 42, s. 244.

27 R. Goodwin, P. Costa, J. Adonu, Social support and its consequences: positive and deficiency values and their complications for support and self-esteem, British Journal of Social Psychology, 2004,43 , s. 466 . 
rem zdrowia, dobrostanu i efektywnego radzenia sobie ze stresem ${ }^{28}$. Wsparcie otrzymywane nie zawsze pełni pozytywną funkcję. Wśród powodów wymienia się nieadekwatność formy wsparcia w stosunku do potrzeb, niewłaściwe źródło pomocy, a także zagrożenie dla poczucia własnej wartości ${ }^{29}$. M. Gleason i wsp. ${ }^{30}$ podkreślają, iż wsparcie otrzymywane będzie odbierane w sposób negatywny wówczas, kiedy wspierany człowiek będzie doświadczał więcej pomocy niż sam jest w stanie jej udzielić. Brak możliwości zwrócenia uzyskiwanego wsparcia może być źródłem stresu, frustracji, gniewu i depresji, podobnie zresztą jak przekazywanie większego wsparcia niż samemu się otrzymało.

Niezależnie od ujmowania wsparcia społecznego, w wielu pracach podkreśla się jego pozytywną rolę dla psychofizycznego funkcjonowania człowieka. Odpowiednie wsparcie podtrzymuje samoocenę, wzmacnia tożsamość osoby oraz mobilizuje zasoby, dzięki czemu jednostka efektywniej radzi sobie $\mathrm{z}$ trudnościami ${ }^{31}$. Emocjonalne oznaki wsparcia zaspokajają potrzebę przyjaźni, dają człowiekowi poczucie przynależności, zmniejszając tym samym poczucie osamotnienia. Współpraca z innymi ludźmi umożliwia realizację celów indywidualnie nieosiągalnych ${ }^{32}$.

Wsparcie społeczne nabiera szczególnego znaczenia w życiu osób z niepełnosprawnością, gdyż jest istotnym elementem rehabilitacji kompleksowej. Warunkiem skutecznego procesu rehabilitacji jest bowiem rozpoznanie obiektywnie istniejących deficytów i wdrożenie adekwatnego wsparcia w kategoriach: emocjonalnych, duchowych, materialnych i innych ${ }^{33}$, przy czym zapotrzebowanie na nie może się różnić u poszczególnych jednostek w zależności od rodzaju niepełnosprawności, stopnia niepełnosprawności, cech osobowości, sytuacji życiowej oraz pełnionych ról społecznych. W literaturze zwraca się uwagę, iż otrzymywanie przez osoby niepełnosprawne adekwatnego do potrzeb wsparcia społecznego współwystępuje z lepszym

28 A. Łuszczyńska, R. Cieślak, Protective, promotive and buffering effects of perceived social support in managerial stress: the moderating role of personality, Anxiety, Stress \& Coping: An International Journal, 2005, 18(3), s. 227-228.

${ }^{29}$ F.H. Norris, K. Kaniasty, Received and perceived social support in times of stress: a test of the social support deterioration deterrence model, Journal of Personality and Social Psychology, 1996, 71(3), s. 498.

${ }^{30}$ M. Gleason $\mathrm{i}$ in., Receiving support as a mixed blessing: evidence for dual effects of support on psychological outcomes, Journal of Personality and Social Psychology, 2008, 94(5), s. 825.

31 A. Chudzicka-Czupała, Bezrobocie. Różne oblicza wsparcia, Katowice 2004, s. 43.

32 P. Warr, Psychologiczne skutki dtugotrwatego bezrobocia, [w:] Człowiek w spotecznej przestrzeni bezrobocia, red. T. Chirkowska-Smolak, A. Chudzicka, Poznań 2004, s. 143-144.

${ }^{33}$ E. Rutkowska, Wsparcie jako element rehabilitacji kompleksowej osób z niepetnosprawnościa, Niepełnosprawność - zagadnienia, problemy, rozwiązania, 2012, 3(4), s. 40-41. 
przystosowaniem do zmian zachodzących w otoczeniu, większą pewnością siebie oraz rzadszym stosowaniem niepożądanych mechanizmów obronnych ${ }^{34}$. Poza tym, osoby te charakteryzują się poczuciem bezpieczeństwa, zaspokojeniem potrzeby przynależności i zmniejszonym stopniem koncentracji na problemie ${ }^{35}$.

Kolejnym zasobem osobistym, poddanym analizie w niniejszej pracy jest samoocena, którą uznaje się za integralną część oraz element wartościującooceniający obrazu własnej osoby ${ }^{36}$. M. Rosenberg ${ }^{37}$ definiuje samoocenę jako dokonywaną i utrzymywaną przez człowieka ocenę własnej osoby. Ocena ta wyraża postawę akceptacji lub nieakceptacji samego siebie. J.D. Brown ${ }^{38}$ podkreśla, iż samoocenę należy identyfikować przez pryzmat emocji biorących w niej udział. Samoocena jest tym, co czujemy kiedy myślimy o sobie, własnych działaniach, cechach, decyzjach, a nie tylko o tym, co sądzimy na swój temat. Nie jest ona wypadkową sądów wartościujących, ale raczej pozytywnym, emocjonalnym nastawieniem do siebie.

Wielu autorów wskazuje na cechy i właściwości jednostki, które mogą być przedmiotem samooceny. W.H. Fitts ${ }^{39}$ wyróżnił w strukturze samooceny trzy poziomy (tożsamość, zadowolenie z siebie, zachowanie), które odniósł do pięciu sfer Ja. Ja fizyczne dotyczy tego, jak jednostka postrzega swoje ciało, stan zdrowia, wygląd fizyczny. Ja moralno-etyczne opisuje Ja z moralnego punktu widzenia. Ja osobiste dotyczy postrzegania własnej osobowości. Ja społeczne odzwierciedla poczucie własnej wartości jednostki $\mathrm{w}$ relacjach międzyludzkich, zaś Ja rodzinne ukazuje ocenę siebie jako członka rodziny oraz percepcję siebie na tle najbliższych osób. Z. Skorny ${ }^{40}$ zwraca uwagę na trzy warunki osobiste będące przedmiotem samooceny, tj. warunki: fizyczne (uroda, stan zdrowia, sprawność ruchowa), psychiczne

${ }^{34}$ J. Kirenko, Dylematy wsparcia spotecznego osób z niepetnosprawnościa, [w:] Wsparcie społeczne w rehabilitacji i resocjalizacji, red. Z. Palak, Z. Bartkowicz, Lublin 2004, s. 12.

${ }_{35} \mathrm{G}$. Teusz, Znaczenie wsparcia społecznego w doświadczaniu przez młodzież krytycznych wydarzeń życiowych, Auxilium Sociale, 2005, 3-4, s. 177.

36 T. Mądrzycki, Osobowość jako system tworzacy i realizujący plan - nowe podejście, Gdańsk 2002, s. 209.

37 Za: L.E. Waters, K.A. Moore, Predicting self-esteem during unemployment: the effect of gender, financial deprivation, alternate roles and social support, Journal of Employment Counseling, 2002, 39, s. 171.

${ }^{38}$ Za: J. Necker, Samowiedza i jej bohater, [w:] Poznaj samego siebie, czyli o źródłach samowie$d z y$, red. A. Niedźwieńska, J. Necker, Warszawa 2009, s. 27.

39 Za: P.A. Gindrich, Funkcjonowanie psychospołeczne uczniów dyslektycznych, Lublin 2004, s. 54 .

40 Za: D. Borecka-Biernat, Strategie radzenia sobie młodzieży w trudnych sytuacjach społecznych, Wrocław 2006, s. 81. 
(sprawność intelektualna, umiejętności, uzdolnienia), społeczne (prestiż społeczny, pozycja zawodowa, sytuacja rodzinna) oraz wyniki własnego działania. Podobne wymiary samooceny wymienia B. Galas ${ }^{41}$ : cechy fizyczne, obejmujące właściwości budowy i funkcjonowania organizmu; cechy psychiczne, które dotyczą właściwości intelektualnych, emocjonalnych i motywacyjnych; cechy społeczne, powstałe i przejawiające się w kontaktach społecznych.

Człowiek ocenia siebie i swoje właściwości przede wszystkim z punktu widzenia możliwości zaspokojenia własnych potrzeb, porównywania osiągnięć ze swoimi aspiracjami lub spełniania wymagań stawianych przez otoczenie. Pozytywna samoocena oddziałuje silnie na oczekiwania, przeżycia emocjonalne, stosunek do innych, poczucie kontroli, nastrój42 oraz wyznacza stosowanie najbardziej efektywnych strategii zaradczych ${ }^{43}$. Prowadzone badania ujawniają, że samoocena wykazuje związki z różnymi dyspozycjami osobowościowymi i wymiarami funkcjonowania emocjonalnego. Stwierdzono, że ujemnie koreluje z lękiem, depresją ${ }^{44}$, neurotycznością ${ }^{45}$, nieśmiałością ${ }^{46}$, a dodatnio wiąże się z satysfakcją z życia ${ }^{47}$ i funkcjonowaniem społecznym $^{48}$.

Widać stąd wyraźnie, iż problematyka samooceny cieszy się dużym zainteresowaniem badaczy. Najważniejszą przyczyną takiego stanu jest niewątpliwie związek samooceny z przystosowaniem indywidualnym i społecznym człowieka. O jej roli w tym kontekście dowodzi fakt, iż poziom przystosowania psychologicznego można zweryfikować m.in. na podstawie samooceny, przy czym ocena ta jest niezależna od pomiarów tzw. temperamentu łatwego i trudnego ${ }^{49}$.

${ }^{41}$ B. Galas, Czynniki wspótwystępujące z samoocena i aspiracjami młodzieży, Psychologia Wychowawcza, 1994, 1, s. 12.

42 Z. Zaborowski, Świadomość i samoświadomość człowieka, Warszawa 1998, s. 193-198.

${ }^{43}$ R. Poprawa, Zasoby osobiste, s. 108.

${ }^{44} \mathrm{~J}$. Blascovich, J. Tomaka, Measures of self-esteem, [in:] Measures of personality and social psychological attitudes, red. J.P. Robinson, P.R. Shaver, L.S. Wrightsman, New York 1991, s. 122123.

${ }^{45}$ D. Watson, J. Suls, J. Haig, Global self-esteem in relation to structural models of personality and affectivity, Journal of Personality and Social Psychology, 2002, 83(1), s. 190.

46 I. Dzwonkowska, Nieśmiatość a wspierajace i trudne relacje z ludźmi, Kraków 2009, s. 143.

47 S.X. Chen i in., Going beyond self-esteem to predict life satisfaction: the Chinese case, Asian Journal of Social Psychology, 2006, 9, s. 28.

${ }_{48}$ M. Łaguna, K. Lachowicz-Tabaczek, I. Dzwonkowska, Skala samooceny Morrisa Rosenberga - polska adaptacja metody, Psychologia Społeczna, 2007, 2, s. 173.

${ }^{49}$ J. Strelau, Psychologia różnic indywidualnych, Warszawa 2006, s. 271. 
Wśród badaczy zauważa się rozbieżność stanowisk na temat poziomu samooceny osób z niepełnosprawnością. Część wyraża opinię, że osoby niepełnosprawne, w porównaniu z pełnosprawnymi, niżej oceniają swoją wartość50, ale są też tacy, według których osoby niepełnosprawne charakteryzuje wyższy poziom samooceny niż osoby pełnosprawne ${ }^{51}$ czy też samoocena zawyżona ${ }^{52}$. Niezależnie jaki poziom samooceny ujawnia człowiek z niepełnosprawnością, musi on przede wszystkim znać siebie i swoje relacje z innymi. Jest to warunek konieczny do satysfakcjonującego funkcjonowania w otaczającym środowisku ${ }^{53}$.

\section{Założenia badań własnych}

Problem główny niniejszej pracy zawiera się w pytaniu: Jakie są zasoby osobiste osób z niepełnosprawnością wzrokową i osób z niepełnosprawnością słuchową? Ponieważ zasoby te są ujęte w aspekcie sensu życia, samooceny i wsparcia społecznego, szczegółowe problemy badawcze przyjęły następującą postać:

1. Jakie jest odczucie sensu życia badanych z niepełnosprawnością wzrokową i badanych z niepełnosprawnością słuchową?

2. Jakiego wsparcia społecznego doświadczają badani z niepełnosprawnością wzrokową $\mathrm{w}$ porównaniu $\mathrm{z}$ analogicznym badanych $\mathrm{z}$ niepełnosprawnością słuchową?

3. Jaką samooceną cechują się badani z niepełnosprawnością wzrokową? Czy różni się ona od tej, jaka jest udziałem badanych z niepełnosprawnością słuchową?

W pracy nie zostały postawione hipotezy, ponieważ problemy badawcze mają charakter pytań dopełnienia. Ze względu na problem główny i problemy szczegółowe wyróżniono następujące zmienne: zmienna niezależna występowanie niepełnosprawności wzrokowej/słuchowej; zmienna zależna - zasoby osobiste analizowane $\mathrm{w}$ wymiarach: poczucie sensu życia, wsparcie społeczne, samoocena.

50 P. Majewicz, Obraz samego siebie a zachowanie młodzieży niepetnoprawnej ruchowo, Kraków 2002, s. 93.

${ }^{51} \mathrm{P}$. Borowiecki, Samoocena osób z niepetnosprawnościa $w$ świetle wybranej literatury $i$ badań własnych, Niepełnosprawność i Rehabilitacja, 2015, 3, s. 136-137.

52 A. Borowiec, Życie z niepetnosprawnościa, [w:] Człowiek niepetnosprawny: sprawność w niepetnosprawności, red. M. Kościelska, B. Aouil, Bydgoszcz 2003, s. 186.

53 J. Kirenko, Wsparcie społeczne osób z niepetnosprawnością, Ryki 2002, s. 123. 
W badaniach wykorzystano następujące narzędzia badawcze: Skala Sensu Życia J.C. Crumbaugha i K.T. Maholicka, Kwestionariusz Wsparcia Społecznego J.S. Norbeck, Skala Samooceny W.H. Fittsa, kwestionariusz ankiety własnej konstrukcji.

Skala Sensu Życia umożliwia dokonanie ilościowego ujęcia posiadania lub braku poczucia sensu życia. Zbudowana jest z trzech części. W części pierwszej znajduje się 20 twierdzeń, które oceniane są na skali od 1 do 7 . Pozwalają one uzyskać wynik ogólny, jak też wyniki szczegółowe odnoszące się do poszczególnych kategorii poczucia sensu życia, tj. cele życia, sens życia, afirmacja życia, ocena siebie, ocena własnego życia, odpowiedzialność i wolność, stosunek do śmierci i samobójstwa. Część druga i trzecia zawiera zdania niedokończone, z tym że stwierdzenia części drugiej dotyczą życia, śmierci i choroby, a trzeciej odnoszą się do tematu dążeń, ambicji i celów życiowych ${ }^{54}$. W badaniach wykorzystano tylko pierwszą część skali.

Kwestionariusz Wsparcia Społecznego służy do określania poziomu wsparcia społecznego oraz jego sieci. Składa się z trzech części. Pierwsza informuje o osobach znaczących, zapewniających byt respondentowi oraz o charakterze relacji łączących go z każdą z nich. Drugą tworzy 8 pytań, adresowanych do osób wymienionych $\mathrm{w}$ pierwszej części, zaś $\mathrm{w}$ trzeciej badani udzielają odpowiedzi na pytanie alternatywne („,Czy podczas minionego roku straciłeś z kimś ważnym kontakt wskutek zmiany pracy, rozwodu, separacji, śmierci lub innych powodów?"). Po zliczeniu punktów, zgodnie z kluczem, otrzymuje się sumy specyficzno-źródłowe i sumy specyficzno-sytuacyjne. Pierwsze określają totalną sumę funkcyjną wsparcia ze strony sieci utworzonej przez osoby znaczące, a drugie informują o poziomie wsparcia społecznego udzielanego przez poszczególne grupy źródłowe w zakresie trzech głównych wymiarów: Emocji, Afirmacji i Pomocy55. W badaniach własnych posłużono się pierwszą i drugą częścią kwestionariusza.

Skala Samooceny składa się ze 100 opisowych twierdzeń, ocenianych na skali 5-punktowej, których używa respondent $\mathrm{w}$ celu dokonania własnej subiektywnej oceny. Zależnie od liczby uzyskanych punktów określa się poziom samooceny badanego. Dokonuje się tego na trzech poziomach (Tożsamość, Akceptacja, Zachowanie) oraz w pięciu kolumnach (Ja fizyczne, Ja moralno-etyczne, Ja osobiste, Ja rodzinne, Ja społeczne). Interpretacji podlegają także: Samokrytycyzm, Wskaźnik prawda/fałsz, Punktacja konfliktów

${ }^{54}$ K.. Popielski, Metody badań frustracji egzystencjalnej i nerwicy noogennej stosowane w logoterapii, Zdrowie Psychiczne, 1982, 1-2, s. 76-77, 89.

55 J. Kirenko, E. Sarzyńska, Bezrobocie, niepetnosprawność, potrzeby, Lublin 2010, s. 170-171. 
netto, Punktacja konfliktów razem, Ogólna punktacja pozytywna, Ogólna zmienność, Zmienność w kolumnach, Zmienność w rzędach, Dystrybucja ${ }^{56}$.

Wymienione narzędzia spełniają warunki poprawności psychometrycznej i były wielokrotnie stosowane przez polskich badaczy z uwzględnieniem różnych grup respondentów.

W celu zebrania danych socjodemograficznych o badanych osobach zastosowano kwestionariusz ankiety własnego układu.

Badaniami objęto 40 osób słabo widzących, tworzących grupę A, i 40 osób słabo słyszących, tworzących grupę B, w wieku 20-30 lat ${ }^{57}$. W obu grupach dominowały kobiety (odpowiednio: 67,50\%; 72,50\%). Najwięcej badanych mieszkało w miastach (odpowiednio: 65\%,60\%) i pochodziło z rodzin pełnych (odpowiednio: 65\%; 82,50\%).

\section{Analiza wyników badań własnych. Poczucie sensu życia badanych osób}

Z przeprowadzonych badań wynika, że poczucia sensu życia w wymiarze ogólnym nie różnicuje istotnie statystycznie badanych z niepełnosprawnością wzrokową i badanych z niepełnosprawnością słuchową. Jednak wyższa wartość średniej w grupie B wskazuje, iż osoby słabo słyszące cechują się korzystniejszą oceną sensu życia w wymiarze ogólnym. Na występujące pomiędzy grupami rozbieżności wskazuje także analiza wymiarów szczegółowych, gdzie pojawiły dwie różnice istotne statystycznie i dwie osiągające poziom zbliżony do granicy ufności. W zdecydowanej większości wymiarów szczegółowych wyższe wartości średnich odnotowano wśród badanych z niepełnosprawnością słuchową. $\mathrm{Na}$ podstawie uzyskanych wyników można zatem przyjąć, iż osoby z grupy $B$, w porównaniu z osobami z grupy A, zwracają znacznie mniejszą uwagę na cele życiowe, dokonując przy tym istotnie wyższej oceny siebie. Poza tym, większą wartość przypisują takim kategoriom, jak: afirmacja życia, ocena własnego życia, sens życia, odpowiedzialność i wolność. W zakresie kategorii stosunek do śmierci nie odnotowano zróżnicowania na poziomie średnich. Uzupełnieniem powyższych prawidłowości jest analiza wyników przeliczonych.

\footnotetext{
56 Tamże, s. 103.

57 Prezentowane wyniki są częścią szerzej zakrojonych badań.
} 
Tabela 1

Poczucie sensu życia osób z grupy A i osób z grupy B - średnie arytmetyczne, odchylenia standardowe, istotność różnic

\begin{tabular}{|l|c|c|c|c|c|c|}
\hline \multirow{2}{*}{ Skale PIL } & \multicolumn{2}{|c|}{ Grupa A } & \multicolumn{2}{c|}{ Grupa B } & \multicolumn{2}{c|}{$\begin{array}{c}\text { Porównanie } \\
\text { średnich }\end{array}$} \\
\cline { 2 - 7 } & $\mathrm{x}$ & $\mathrm{s}$ & $\mathrm{x}$ & $\mathrm{s}$ & $\mathrm{t}$ & $\mathrm{p}$ \\
\hline Cele życia & 5,21 & 0,75 & 4,81 & 0,84 & 2,26 & $0,026^{*}$ \\
\hline Sens życia & 4,05 & 0,74 & 4,26 & 0,88 & $-1,15$ & 0,255 \\
\hline Afirmacja życia & 3,18 & 0,85 & 3,55 & 0,87 & $-1,95$ & $0,055 \sim$ \\
\hline Ocena siebie & 3,83 & 0,69 & 4,14 & 0,67 & $-2,05$ & $0,044^{*}$ \\
\hline $\begin{array}{l}\text { Ocena własnego } \\
\text { życia }\end{array}$ & 3,96 & 0,63 & 4,26 & 0,81 & $-1,84$ & $0,069 \sim$ \\
\hline $\begin{array}{l}\text { Odpowiedzialność } \\
\text { i wolność }\end{array}$ & 4,38 & 0,96 & 4,43 & 0,84 & $-0,25$ & 0,805 \\
\hline Stosunek do śmierci & 4,46 & 1,38 & 4,44 & 1,42 & 0,08 & 0,937 \\
\hline Wynik ogólny & 84,15 & 6,41 & 85,55 & 9,69 & $-0,76$ & 0,448 \\
\hline
\end{tabular}

* Istotne statystycznie.

$\sim$ Zbliżone do istotności statystycznej.

Tabela 2

Poczucie sensu życia osób z grupy A i osób z grupy B58 - wyniki przeliczone

\begin{tabular}{|c|c|c|c|c|c|c|}
\hline \multirow[b]{2}{*}{ Skale PIL } & \multicolumn{3}{|c|}{ Grupa A } & \multicolumn{3}{|c|}{ Grupa B } \\
\hline & $\begin{array}{l}\text { wyniki } \\
\text { niskie }\end{array}$ & $\begin{array}{c}\text { wyniki } \\
\text { przecietne }\end{array}$ & $\begin{array}{c}\text { wyniki } \\
\text { wysokie }\end{array}$ & $\begin{array}{l}\text { wyniki } \\
\text { niskie }\end{array}$ & $\begin{array}{c}\text { wyniki } \\
\text { przecietne }\end{array}$ & $\begin{array}{c}\text { wyniki } \\
\text { wysokie }\end{array}$ \\
\hline Cele życia & $5(12,50 \%)$ & $29(72,50 \%)$ & $6(15,00 \%)$ & $4(10,00 \%)$ & $31(77,50 \%)$ & $5(12,50 \%)$ \\
\hline Sens życia & $4(10,00 \%)$ & $31(77,50 \%)$ & $5(12,50 \%)$ & $6(15,00 \%)$ & $30(75,00 \%)$ & $4(10,00 \%)$ \\
\hline Afirmacja życia & $7(17,50 \%)$ & $27(67,50 \%)$ & $6(15,00 \%)$ & $5(12,50 \%)$ & $26(65,00 \%)$ & $9(22,50 \%)$ \\
\hline Ocena siebie & $8(20,00 \%)$ & $27(67,50 \%)$ & $5(12,50 \%)$ & $4(10,00 \%)$ & $30(75,00 \%)$ & $6(15,00 \%)$ \\
\hline $\begin{array}{l}\text { Ocena własnego } \\
\text { życia }\end{array}$ & $1(2,50 \%)$ & $36(90,00 \%)$ & $3(7,50 \%)$ & $1(2,50 \%)$ & $35(87,50 \%)$ & $4(10,00 \%)$ \\
\hline $\begin{array}{l}\text { Odpowiedzialność } \\
\text { i wolność }\end{array}$ & $3(7,50 \%)$ & $28(70,00 \%)$ & $9(22,50 \%)$ & $8(20,00 \%)$ & $25(62,50 \%)$ & $7(17,50 \%)$ \\
\hline $\begin{array}{l}\text { Stosunek do } \\
\text { śmierci }\end{array}$ & $6(15,00 \%)$ & $25(62,50 \%)$ & $9(22,50 \%)$ & $8(20,00 \%)$ & $25(62,50 \%)$ & $7(17,50 \%)$ \\
\hline Wynik ogólny & $6(15,00 \%)$ & $30(75,00 \%)$ & $4(10,00 \%)$ & $7(17,50 \%)$ & $27(67,50 \%)$ & $6(15,00 \%)$ \\
\hline
\end{tabular}

Szczegółowe zestawienie wyników przeliczonych wskazuje, iż w wymiarze ogólnym odsetek osób z niepełnosprawnością wzrokową otrzymujących wyniki niskie jest zbliżony do odsetka osób z niepełnosprawnością słuchową, większy jest jednak w zakresie wyników przeciętnych i mniejszy w wysokich. Rozkład wyników kategorii afirmacja życia również różnicuje

58 Wyniki przeliczone wyznaczono z wykorzystaniem metody uwzględniającej średnią arytmetyczną i odchylenie standardowe. 
badane osoby. Nie obserwuje się wprawdzie rozbieżności pomiędzy grupami $\mathrm{w}$ zakresie wyników przeciętnych, ale wyraźne pojawiają się już w przypadku wyników niskich i wysokich, przy czym pierwsze przeważają w grupie A, drugie zaś w grupie B. Także w kategorii ocena siebie odsetek badanych słabo widzących z wynikami niskimi jest większy od analogicznego badanych słabo słyszących, ale mniejszy już w obrębie wartości przeciętnych i zbliżony w wysokich, co tym samym różnicuje tę kategorię w porównaniu z innymi. Jeszcze inny rozkład wartości przeliczonych obserwuje się w zakresie kategorii odpowiedzialność i wolność oraz stosunek do śmierci. W pierwszym przypadku odsetek osób z niepełnosprawnością wzrokową uzyskujących wyniki niskie jest zdecydowanie mniejszy od analogicznego osób z niepełnosprawnością słuchową, większy jednak w zakresie wyników przeciętnych i wysokich. Natomiast, w drugim identycznym wartościom przeciętnym towarzyszy zróżnicowanie $\mathrm{w}$ wynikach niskich i wysokich. W układzie wyników przeliczonych kategorii: cele życia, sens życia i ocena własnego życia zaznaczyły się niewielkie różnice pomiędzy grupami.

\section{Wsparcie społeczne badanych osób}

Porównanie wyników w zakresie wsparcia społecznego ujawniło, iż zaznaczyły się pewne różnice pomiędzy badanymi z niepełnosprawnością wzrokową i badanymi $\mathrm{z}$ niepełnosprawnością słuchową. $\mathrm{W}$ jednym $\mathrm{z}$ wymiarów szczegółowych rozbieżność osiągnęła poziom istotności statystycznej, a we wszystkich, jak również w wyniku ogólnym, wyższe średnie arytmetyczne osiągnęli badani z grupy A. Można zatem przyjąć, iż osoby słabo widzące $\mathrm{w}$ porównaniu $\mathrm{z}$ osobami słabo słyszącymi wskazują na większy zakres dostarczanego im wsparcia ogólnego. Niepełnosprawni wzrokowo czują się w większym zakresie akceptowani, podziwiani i szanowani przez najbliższych. Cechuje ich także bardziej nasilone poczucie pewności, iż są obdarzani zaufaniem ze strony swojej sieci wsparcia, zwłaszcza w kwestii posiadanych zdolności i kompetencji koniecznych $w$ podejmowanych działaniach, jak i otrzymywania znacznie większego zakresu pomocy praktycznej (materialnej, funkcjonalnej). Więcej informacji na temat wsparcia badanych osób dostarcza analiza wyników przeliczonych. 
Tabela 3 Wsparcie społeczne osób z grupy A i osób z grupy B - średnie arytmetyczne, odchylenia standardowe, istotność różnic

\begin{tabular}{|l|c|c|c|c|c|c|}
\hline \multirow{2}{*}{ Skale NSSQ } & \multicolumn{2}{|c|}{ Grupa A } & \multicolumn{2}{c|}{ Grupa B } & \multicolumn{2}{c|}{$\begin{array}{c}\text { Porównanie } \\
\text { średnich }\end{array}$} \\
\cline { 2 - 7 } & $\mathrm{x}$ & $\mathrm{s}$ & $\mathrm{x}$ & $\mathrm{s}$ & $\mathrm{t}$ & $\mathrm{p}$ \\
\hline Emocje & 54,87 & 26,51 & 46,15 & 17,20 & 1,75 & 0,085 \\
\hline Afirmacja & 52,33 & 26,21 & 44,45 & 15,91 & 1,62 & 0,108 \\
\hline Pomoc & 55,65 & 25,38 & 45,35 & 17,42 & 2,12 & $0,038^{*}$ \\
\hline $\begin{array}{l}\text { Suma funk- } \\
\text { cjonalna }\end{array}$ & 141,35 & 78,72 & 115,15 & 59,00 & 1,68 & 0,098 \\
\hline
\end{tabular}

* Istotne statystycznie.

Tabela 4

Wsparcie społeczne osób z grupy A i osób z grupy B - wyniki przeliczone ${ }^{59}$

\begin{tabular}{|l|c|c|c|c|c|c|}
\hline \multirow{2}{*}{ Skale NSSQ } & \multicolumn{3}{|c|}{ Grupa A } & \multicolumn{3}{c|}{ Grupa B } \\
\cline { 2 - 7 } & $\begin{array}{c}\text { wyniki } \\
\text { niskie }\end{array}$ & $\begin{array}{c}\text { wyniki } \\
\text { przeciętne }\end{array}$ & $\begin{array}{c}\text { wyniki } \\
\text { wysokie }\end{array}$ & $\begin{array}{c}\text { wyniki } \\
\text { niskie }\end{array}$ & $\begin{array}{c}\text { wyniki } \\
\text { przeciętne }\end{array}$ & $\begin{array}{c}\text { wyniki } \\
\text { wysokie }\end{array}$ \\
\hline Emocje & $4(10,00 \%)$ & $30(75,00 \%)$ & $6(15,00 \%)$ & $6(15,00 \%)$ & $28(70,00 \%)$ & $6(15,00 \%)$ \\
\hline Afirmacja & $4(10,00 \%)$ & $29(72,50 \%)$ & $7(17,50 \%)$ & $7(20,00 \%)$ & $26(65,00 \%)$ & $6(15,00 \%)$ \\
\hline Pomoc & $5(12,50 \%)$ & $30(75,00 \%)$ & $5(12,50 \%)$ & $5(12,50 \%)$ & $30(75,00 \%)$ & $5(12,50 \%)$ \\
\hline $\begin{array}{l}\text { Suma funk- } \\
\text { cjonalna }\end{array}$ & $7(17,50 \%)$ & $26(65,00 \%)$ & $7(17,50 \%)$ & $9(22,50 \%)$ & $25(62,50 \%)$ & $6(15,00 \%)$ \\
\hline
\end{tabular}

Z rozkładu wartości przeliczonych wynika, iż odsetek badanych z grupy A otrzymujących w wymiarze ogólnym wyniki niskie jest mniejszy od analogicznego w grupie B, przy niewielkim zróżnicowaniu w zakresie wyników przeciętnych i wysokich. Jednak korzystniejsze wyniki są udziałem osób słabo widzących. Podobną strukturę wartości przeliczonych obserwuje się w skalach Emocje i Afirmacja. Natomiast w skali Pomoc nie obserwuje się żadnych różnic pomiędzy grupami w obszarze wartości przeliczonych.

\section{Samoocena badanych osób}

Analiza zebranych danych pozwala przyjąć, iż w zakresie samooceny występują istotne statystycznie różnice pomiędzy badanymi. Spośród siedemnastu wskaźników Skali Samooceny, w dziesięciu zaznaczyły się rozbieżności na poziomie ufności. W dwunastu wskaźnikach kierunek różnicy pomiędzy średnimi jest korzystniejszy dla grupy B, zaś w pięciu dla grupy A. Wyniki ujawniają, iż osoby $\mathrm{z}$ niepełnosprawnością słuchową definiują

${ }^{59}$ Jak wyżej. 
własne Ja w sposób znacznie bardziej harmonijny niż osoby z niepełnosprawnością wzrokową, a więc z jednej strony afirmują to, co wchodzi w skład ich Ja, a z drugiej odrzucają to, czego ono nie obejmuje. Przejawiają istotnie mniejszą skłonność do konfliktu zaprzeczenia, wskazując tym samym, że nie zaprzeczają nadmiernie swoim cechom negatywnym względem sposobu, w jaki potwierdzają swoje cechy pozytywne. Znacznie częściej postrzegają siebie jako osoby wartościowe, lubiące i akceptujące siebie oraz ufające sobie. Mają istotnie silniejsze niż badani z niepełnosprawnością wzrokową poczucie własnej tożsamości, stawiają sobie większe wymagania i ujawniają znacznie wyższy poziom samoakceptacji i samozadowolenia. Osoby z grupy B, w porównaniu $\mathrm{z}$ osobami z grupy A, zwracają istotnie większą uwagę na swoje ciało, zdrowie, wygląd fizyczny i mają bardziej nasiloną tendencję do przypisywania sobie cech dodatnich w odniesieniu do kierowania się wartościami moralnymi w swoim życiu.

Tabela 5

Samoocena osób z grupy A i osób z grupy B - średnie arytmetyczne, odchylenia standardowe, istotność różnic

\begin{tabular}{|l|c|c|c|c|c|c|}
\hline \multirow{2}{*}{ Skale TSCS } & \multicolumn{2}{|c|}{ Grupa A } & \multicolumn{2}{c|}{ Grupa B } & \multicolumn{2}{c|}{$\begin{array}{c}\text { Porównanie } \\
\text { średnich }\end{array}$} \\
\cline { 2 - 7 } & $\mathrm{x}$ & $\mathrm{s}$ & $\mathrm{x}$ & $\mathrm{s}$ & $\mathrm{t}$ & $\mathrm{p}$ \\
\hline Samokrytycyzm & 34,78 & 7,12 & 32,45 & 7,89 & 1,38 & 0,170 \\
\hline $\begin{array}{l}\text { Wskaźnik prawda/ } \\
\text { fałsz }\end{array}$ & 1,26 & 0,40 & 1,96 & 1,27 & $-3,33$ & $0,001^{*}$ \\
\hline $\begin{array}{l}\text { Punktacja konfliktów } \\
\text { netto }\end{array}$ & 67,28 & 34,40 & 49,23 & 33,20 & 2,39 & $0,019^{*}$ \\
\hline $\begin{array}{l}\text { Punktacja konfliktów } \\
\text { razem }\end{array}$ & 74,25 & 29,37 & 63,50 & 27,64 & 1,69 & 0,096 \\
\hline $\begin{array}{l}\text { Ogólna punktacja pozy- } \\
\text { tywna }\end{array}$ & 271,58 & 16,06 & 288,35 & 29,40 & $-3,17$ & $0,002^{*}$ \\
\hline Tożsamość & 84,33 & 9,26 & 89,73 & 10,00 & $-2,51$ & $0,014^{*}$ \\
\hline Akceptacja & 91,23 & 7,43 & 100,80 & 15,02 & $-3,61$ & $0,001^{*}$ \\
\hline Zachowanie & 96,15 & 8,37 & 97,85 & 10,72 & $-0,79$ & 0,431 \\
\hline Ja fizyczne & 53,25 & 11,71 & 59,28 & 12,26 & $-2,25$ & $0,027^{*}$ \\
\hline Ja moralno-etyczne & 51,05 & 11,51 & 57,45 & 5,05 & $-3,22$ & $0,001^{*}$ \\
\hline Ja osobiste & 48,73 & 10,50 & 57,50 & 7,33 & $-4,33$ & $0,000^{*}$ \\
\hline Ja rodzinne & 51,45 & 11,64 & 59,55 & 7,76 & $-3,66$ & $0,000^{*}$ \\
\hline Ja społeczne & 51,20 & 11,95 & 57,78 & 6,37 & $-3,07$ & $0,003^{*}$ \\
\hline Ogólna zmienność & 40,50 & 14,68 & 43,55 & 17,60 & $-0,84$ & 0,402 \\
\hline $\begin{array}{l}\text { Zmienność w kolum- } \\
\text { nach }\end{array}$ & 17,78 & 8,91 & 20,13 & 10,30 & $-1,09$ & 0,279 \\
\hline Zmienność w rzędach & 23,63 & 9,08 & 24,68 & 10,49 & $-0,48$ & 0,663 \\
\hline Dystrybucja & 114,80 & 36,41 & 103,53 & 38,16 & 1,35 & 0,180 \\
\hline
\end{tabular}

* Istotne statystycznie. 
Cechuje je także znacznie wyższe poczucie własnej wartości, korzystniejsza ocena swojej osobowości w odrębności od swojego ciała i stosunku do innych, bardziej pozytywny obraz siebie jako członka rodziny i istotnie częstsze przypisywanie sobie pozytywnych cech w wymiarze społecznym. $\mathrm{Z}$ analizy pozostałych skal, $\mathrm{w}$ których nie pojawiły się znaczące różnice pomiędzy grupami wynika, iż badani słabo słyszący pozytywniej oceniają swoje zachowanie, wykazując się tendencją do przypisywania sobie wyższych ocen, rzadziej ujawniają konflikty w zakresie odbioru własnego Ja i niestabilność emocjonalną. Natomiast, osoby z grupy A w mniejszym stopniu niż osoby z grupy B mają skłonność do ukazywania siebie w lepszym świetle, cechuje je większy samokrytycyzm. Odznaczają się też słabszą tendencją do braku jedności pomiędzy poszczególnymi sferami własnego Ja i mniejszą skłonnością do zmienności percepcyjnej poszczególnych sfer obrazu siebie. Rzadziej izolują pewne sfery własnego Ja od pozostałych sfer i ujawniają większe zdecydowanie i pewność siebie w tym co robią. Uzupełnieniem powyższych danych jest analiza struktury wartości przeliczonych.

Z zestawienia danych wynika, że odsetek osób słabo widzących otrzymujących w skali Wskaźnik prawda/fałsz wyniki niskie i wysokie jest większy od analogicznego osób słabo słyszących, jednak mniejszy w obrębie wartości przeciętnych. Również rozkład wyników skali Punktacja konfliktów razem różnicuje badane grupy, gdyż odsetek osób z grupy A z wynikami niskimi przewyższa porównywalny osób z grupy $\mathrm{B}$, przy zbliżonych odsetkach $\mathrm{w}$ wynikach przeciętnych i mniejszych w zakresie wysokich. Podobną strukturę wartości przeliczonych, oprócz wyników przeciętnych, gdzie zaznaczyła się pewna rozbieżność, zauważa się w przypadku skal Ja fizyczne i Ja rodzinne. Także w skali Ogólna punktacja pozytywna odsetek osób z niepełnosprawnością wzrokową z wynikami wysokimi jest mniejszy od analogicznego osób z niepełnosprawnością słuchową, ale większy w obrębie wartości przeciętnych i zbliżony w niskich. Identyczną sytuację zauważa się w skali Zachowanie, a bardzo podobną w skalach Ja moralno-etyczne i Ja społeczne. Inny rozkład wartości przeliczonych dotyczy kolejnych skal TSCS, tzn. Tożsamość, Ogólna zmienność, Zmienność w rzędach, gdzie odsetki badanych z obu grup z wynikami niskimi są identyczne lub zbliżone, przy zróżnicowaniu w obrębie wartości przeciętnych i wysokich, przy czym odsetek pierwszych jest większy w grupie B, a drugich w grupie A. Wyniki przeliczone uzyskane w skalach Akceptacja i Dystrybucja w swym układzie także odbiegają od zaprezentowanych powyżej i różnicują badane grupy, gdyż odsetek osób słabo widzących osiągających wyniki przeciętne jest 
mniejszy od odsetka osób słabo słyszących, ale większy w zakresie wartości niskich i równy w wysokich. Jeszcze inny rozkład wartości przeliczonych obserwuje się w skalach Ja osobiste i Zmienność w kolumnach. Odsetek badanych z niepełnosprawnością wzrokową uzyskujących w skali Ja osobiste wyniki niskie i wysokie jest mniejszy od analogicznego badanych z niepełnosprawnością słuchową, ale większy $\mathrm{w}$ wartościach przeciętnych. Natomiast $\mathrm{w}$ skali Zmienność $\mathrm{w}$ kolumnach zbliżonym odsetkom $\mathrm{w}$ obszarze wartości przeciętnych towarzyszy zróżnicowanie w zakresie wyników niskich i wysokich. W grupie A obserwuje się większy odsetek wyników wysokich, a w grupie B niskich. Natomiast, w skalach Samokrytycym i Punktacja konfliktów netto zauważa się niewielkie różnice pomiędzy grupami w strukturze wartości przeliczonych, które są jednak wyraźniejsze w skali Punktacja konfliktów netto.

Tabela 6

Samoocena osób z grupy A i osób z grupy B - wyniki przeliczone 60

\begin{tabular}{|l|l|c|c|c|c|c|}
\hline \multirow{2}{*}{ Skale TSCS } & \multicolumn{3}{|c|}{ Grupa A } & \multicolumn{3}{c|}{ Grupa B } \\
\cline { 2 - 6 } & $\begin{array}{c}\text { wyniki } \\
\text { niskie }\end{array}$ & $\begin{array}{c}\text { wyniki } \\
\text { przeciętne }\end{array}$ & $\begin{array}{c}\text { wyniki } \\
\text { wysokie }\end{array}$ & $\begin{array}{c}\text { wyniki } \\
\text { niskie }\end{array}$ & $\begin{array}{c}\text { wyniki } \\
\text { przeciętne }\end{array}$ & $\begin{array}{c}\text { wyniki } \\
\text { wysokie }\end{array}$ \\
\hline Samokrytycyzm & $8(20,00 \%)$ & $25(62,50 \%)$ & $7(17,50 \%)$ & $8(20,00 \%)$ & $26(65,00 \%)$ & $6(15,00 \%)$ \\
\hline Wskaźnik prawda/fałsz & $6(15,00 \%)$ & $25(62,50 \%)$ & $9(22,50 \%)$ & $2(5,00 \%)$ & $31(77,50 \%)$ & $7(17,50 \%)$ \\
\hline $\begin{array}{l}\text { Punktacja konfliktów } \\
\text { netto }\end{array}$ & $6(15,00 \%)$ & $29(72,50 \%)$ & $5(12,50 \%)$ & $5(12,50 \%)$ & $28(70,00 \%)$ & $7(17,50 \%)$ \\
\hline $\begin{array}{l}\text { Punktacja konfliktów } \\
\text { razem }\end{array}$ & $7(17,50 \%)$ & $27(67,50 \%)$ & $6(15,00 \%)$ & $4(10,00 \%)$ & $28(70,00 \%)$ & $8(20,00 \%)$ \\
\hline $\begin{array}{l}\text { Ogólna punktacja pozy- } \\
\text { tywna }\end{array}$ & $7(17,50 \%)$ & $27(67,50 \%)$ & $6(15,00 \%)$ & $8(20,00 \%)$ & $24(60,00 \%)$ & $8(20,00 \%)$ \\
\hline Tożsamość & $6(15,00 \%)$ & $27(67,50 \%)$ & $7(17,50 \%)$ & $6(15,00 \%)$ & $29(72,50 \%)$ & $5(12,50 \%)$ \\
\hline Akceptacja & $7(17,50 \%)$ & $26(65,00 \%)$ & $7(17,50 \%)$ & $2(5,00 \%)$ & $31(77,50 \%)$ & $7(20,00 \%)$ \\
\hline Zachowanie & $5(12,50 \%)$ & $31(77,50 \%)$ & $4(10,00 \%)$ & $4(10,00 \%)$ & $27(67,50 \%)$ & $9(22,50 \%)$ \\
\hline Ja fizyczne & $4(10,00 \%)$ & $33(82,50 \%)$ & $3(7,5071 \%)$ & $2(5,00 \%)$ & $33(82,50 \%)$ & $5(12,50 \%)$ \\
\hline Ja moralno-etyczne & $7(17,50 \%)$ & $32(80,00 \%)$ & $1(2,50 \%)$ & $7(17,50 \%)$ & $25(62,50 \%)$ & $8(20,00 \%)$ \\
\hline Ja osobiste & $4(10,00 \%)$ & $35(87,50 \%)$ & $1(2,50 \%)$ & $6(15,00 \%)$ & $26(65,00 \%)$ & $8(20,00 \%)$ \\
\hline Ja rodzinne & $10(25,00 \%)$ & $29(72,50 \%)$ & $1(2,50 \%)$ & $7(17,50 \%)$ & $24(60,00 \%)$ & $9(22,50 \%)$ \\
\hline Ja społeczne & $4(10,00 \%)$ & $34(85,00 \%)$ & $2(5,00 \%)$ & $4(10,00 \%)$ & $30(75,00 \%)$ & $6(15,00 \%)$ \\
\hline Ogólna zmienność & $4(10,00 \%)$ & $28(70,00 \%)$ & $8(20,00 \%)$ & $5(12,50 \%)$ & $32(80,00 \%)$ & $3(7,50 \%)$ \\
\hline Zmienność w kolumnach & $1(2,50 \%)$ & $33(82,50 \%)$ & $6(15,00 \%)$ & $3(7,50 \%)$ & $34(85,00 \%)$ & $3(7,50 \%)$ \\
\hline Zmienność w rzędach & $6(15,00 \%)$ & $27(67,50 \%)$ & $6(15,00 \%)$ & $5(12,50 \%)$ & $31(77,50 \%)$ & $4(10,00 \%)$ \\
\hline Dystrybucja & $7(17,50 \%)$ & $27(67,50 \%)$ & $6(15,00 \%)$ & $4(10,00 \%)$ & $30(75,00 \%)$ & $6(15,00 \%)$ \\
\hline
\end{tabular}

${ }^{60}$ Jak wyżej. 


\section{Zakończenie}

Celem podjętych badań było zdiagnozowanie zasobów osobistych badanych z niepełnosprawnością wzrokową i badanych z niepełnosprawnością słuchową.

Przeprowadzone analizy pozwoliły scharakteryzować poczucie sensu życia osób słabo widzących i porównać je z tym, jakie cechuje osoby słabo słyszące. Z badań wynika, że poczucia sensu życia w wymiarze ogólnym nie różnicuje istotnie statystycznie osób z obydwu grup. Można jedynie powiedzieć o nieco niższym poczuciu sensu życia badanych z niepełnosprawnością wzrokową, w porównaniu z badanymi z niepełnosprawnością słuchową. Na występujące pomiędzy grupami rozbieżności wskazuje także analiza wymiarów szczegółowych, gdzie pojawiły dwie różnice istotne statystycznie i dwie osiągające poziom zbliżony do granicy ufności. Okazało się bowiem, że badani $\mathrm{z}$ grupy $\mathrm{A}, \mathrm{w}$ porównaniu $\mathrm{z}$ badanymi z grupy $\mathrm{B}$, znacznie wyżej preferują cele życiowe, a istotnie niżej oceniają siebie. Ujawniają tendencję do słabszej afirmacji życia i oceny własnego życia oraz niższej preferencji sensu życia, odpowiedzialności i wolności. Można zatem wskazać, iż osoby słabo słyszące są bardziej skłonne do odczuwania sensu własnego życia. Jest to bardzo ważna umiejętność, gdyż, jak podkreśla K. Popielski61, odczuwanie sensu własnego życia warunkuje stabilność emocjonalną, odporność na przeszkody i satysfakcję z życia. Pozwala także na odnalezienie sensu własnej egzystencji i umożliwia doskonalenie osobowości.

Badania ujawniły, że wsparcie społeczne w wymiarze ogólnym nie różnicuje istotnie statystycznie badanych grup. Na podstawie wartości średnich arytmetycznych można jednak przyjąć, iż osoby słabo widzące, w porównaniu z osobami słabo słyszącymi, wskazują na większy zakres dostarczanego im wsparcia ogólnego. Pewne rozbieżności zaznaczyły się także w wymiarach szczegółowych wsparcia, gdzie zarysowała się jedna różnica na poziomie ufności. Z przeprowadzonej analizy wynika, że badanych z grupy A charakteryzuje odczuwanie znacznie większego zakresu pomocy praktycznej, a także nieco większe poczucie pozostawania szanowanymi, podziwianymi, szczęśliwymi, wspieranymi przez swoich najbliższych $\mathrm{w}$ podejmowanych działaniach i obdarzanymi zaufaniem. Interpretując uzyskane wyniki, należy podkreślić, iż chodzi tutaj o wparcie spostrzegane, oceniane wprawdzie bardzo subiektywnie, ale jak to już podkreślano o istotnym znaczeniu dla psychospołecznego funkcjonowania człowieka. Przypisuje się mu bo-

${ }^{61}$ K. Popielski, za: L. Bobkowicz-Lewartowska, Poczucie sensu życia osób z zaburzeniami nerwicowymi, Psychiatria i Psychologia Kliniczna, 2013, 13/1, s. 34. 
wiem ważną rolę $\mathrm{w}$ zachowaniu zdrowia oraz utrzymaniu dobrego samopoczucia fizycznego i emocjonalnego. W sytuacji choroby czy niepełnosprawności efektywność udzielanego wsparcia sprawia, że osoby podnoszą swą zdolność radzenia sobie z obniżaniem wydolności fizycznej i psychicznej oraz kumulowaniem się strat $\mathrm{w}$ różnych obszarach aktywności62.

Intersujące wyniki uzyskano porównując samoocenę osób słabo widzących i samoocenę osób słabo słyszących. W dziesięciu wskaźnikach samooceny, spośród siedemnastu, pojawiły się istotne statystycznie różnice pomiędzy grupami. Wyniki pokazują, że osoby $\mathrm{z}$ niepełnosprawnością słuchową, w porównaniu z osobami z niepełnosprawnością wzrokową, definiują własne Ja w sposób znacznie bardziej harmonijny, przejawiają mniejszą skłonność do konfliktu zaprzeczenia i częściej postrzegają siebie jako osoby wartościowe. Mają istotnie silniejsze poczucie własnej tożsamości, wyższy poziom samoakceptacji, zwracają większą uwagę na swoje ciało, zdrowie i wartości moralne. Cechuje je także znacznie bardziej korzystna ocena swojej osobowości, pozytywny obraz siebie jako członka rodziny oraz przypisywanie sobie pozytywnych cech $w$ wymiarze społecznym. Poza tym, badani słabo słyszący nieco pozytywniej oceniają swoje zachowanie, wykazując się tendencją do przypisywania sobie wyższych ocen, rzadziej ujawniają konflikty w zakresie odbioru własnego Ja i niestabilność emocjonalną. Jeśli chodzi o osoby słabo widzące, to $\mathrm{w}$ nieco mniejszym stopniu, $\mathrm{w}$ porównaniu z osobami słabo słyszącymi, są skłonne do ukazywania siebie w lepszym świetle i zmienności percepcyjnej poszczególnych sfer obrazu siebie. Równocześnie rzadziej izolują pewne sfery własnego Ja od pozostałych i ujawniają większe zdecydowanie oraz pewność siebie w tym co robią. Widać stąd wyraźnie, iż badani z niepełnosprawnością słuchową oceniają siebie pozytywniej niż badani z niepełnosprawnością wzrokową. Warto w tym miejscu powołać się na A. Rakowską ${ }^{63}$, która podkreśliła, iż każdy człowiek, a zwłaszcza osoba z niepełnosprawnością jest narażony na różne ograniczenia, jakie wiążą się z życiem w określonym czasie i miejscu. Ważna jest podmiotowość człowieka, której istotny element stanowi analiza percepcji siebie, ponieważ warunkuje ona konkretny sposób działania, zapewnia możliwość wchodzenia w interakcje społeczne i daje poczucie sprawstwa.

Na podstawie zaprezentowanych wyników można mówić o znaczącym potencjale, jakim dysponują badane osoby z niepełnosprawnością, a zwłasz-

62 Por. S. Steuden, W. Okła, Czynniki sprzyjajace podnoszeniu jakości życia w sytuacji choroby, [w:] Jakość życia w chorobie, red. S. Steuden, W. Okła, Lublin 2006, s. 201.

63 A. Rakowska, Kształcenie akademickie a niepetnosprawność. Doświadczenia w pracy ze studentami, [w:] Student z niepetnosprawnościa w szkole wyższej, red. B. Tylewska-Nowak, W. Dykcik, Poznań 2013, s. 60. 
cza osoby słabo słyszące, gdyż jedynie w zakresie samooceny pojawiły się bardzo wyraźnie różnice pomiędzy grupami. Z drugiej jednak strony zastanawia, dlaczego te różnice są aż tak duże. Aby na to pytanie odpowiedzieć, należałoby więc znacznie rozszerzyć zakres eksploracji. Wydaje się również zasadne uwzględnienie $w$ badaniach zmiennej aprobaty społecznej, co przy takim rozkładzie wyników mogłoby poszerzyć płaszczyznę interpretacji.

Współczesna psychologia zdrowia coraz więcej miejsca poświęca problematyce zasobów osobistych, widząc w nich czynniki sprzyjające zdrowiu i jakości życia jednostki. Ich rola, istotna w życiu każdego człowieka, jeszcze bardziej wzrasta $\mathrm{w}$ sytuacji trudnej, jaką jest niewątpliwie obciążenie jednostki niepełnosprawnością wzrokową czy słuchową, co tym bardziej uzasadnia potrzebę prowadzenia dalszych badań w tym kierunku.

\section{BIBLIOGRAFIA}

Blascovich J., Tomaka J., Measures of self-esteem, [w:] Measures of personality and social psychological attitudes, red. J.P. Robinson, P.R. Shaver, L.S. Wrightsman, Academic Press, New York 1991.

Bobkowicz-Lewartowska L., Poczucie sensu życia jako wskaźnik psychicznego dobrostanu u osób z zaburzeniami widzenia, [w:] Wspótczesne problemy pedagogiki specjalnej, red. U. Bartnikowska, Cz. Kosakowski, A. Krause, Wydawnictwo Uniwersytetu Warmińsko-Mazurskiego, Olsztyn 2008.

Bobkowicz-Lewartowska L., Poczucie sensu życia osób z zaburzeniami nerwicowymi, Psychiatria i Psychologia Kliniczna, 2013, 13/1.

Borecka-Biernat D., Strategie radzenia sobie młodzieży w trudnych sytuacjach społecznych, Wydawnictwo Uniwersytetu Wrocławskiego, Wrocław 2006.

Borowiec A., Życie z niepetnosprawnościa, [w:] Człowiek niepetnosprawny. Sprawność w niepetnosprawności, red. M. Kościelska, B. Aouil, Wydawnictwo AB, Bydgoszcz 2003.

Borowiecki P., Samoocena osób z niepetnosprawnościa w świetle wybranej literatury $i$ badań własnych, Niepełnosprawność i Rehabilitacja, 2015, 3.

Brzezińska M., Proaktywna starość. Strategie radzenia sobie ze stresem w okresie późnej dorostości, Wydawnictwo Difin, Warszawa 2011.

Chen S.X., Cheung F.M., Bond M.H., Leury J., Going beyond self-esteem to predict life satisfaction: the Chinese case, Asian Journal of Social Psychology, 2006, 9.

Chudzicka-Czupała A., Bezrobocie. Różne oblicza wsparcia, Wydawnictwo Uniwersytetu Śląskiego, Katowice 2004.

Dzwonkowska I., Nieśmiałość a wspierająe i trudne relacje z ludźmi, Oficyna Wydawnicza Impuls, Kraków 2009.

Galas B., Czynniki wspótwystępujące z samoocena i aspiracjami młodzieży, Psychologia Wychowawcza, 1994, 1.

Gindrich P.A., Funkcjonowanie psychospołeczne uczniów dyslektycznych, Wydawnictwo Uniwersytetu Marii Curie-Skłodowskiej, Lublin 2004. 
Gleason M., Linda M., Shrout P., Bolger N., Receiving support as a mixed blessing: evidence for dual effects of support on psychological outcomes, Journal of Personality and Social Psychology, 2008, 94(5).

Głaz S., Sens życia, Wydawnictwo WAM, Kraków 1998.

Gołaszewska M., Estetyka wobec pytań egzystencjalnych. Funkcje piękna w życiu młodzieży niepetnosprawnej, [w:] Wymiary piękna, red. M. Gołaszewska, Wydawnictwo Uniwersytetu Jagiellońskiego, Kraków 1998.

Goodwin R., Costa P., Adonu J., Social support and its consequences: positive and deficiency values and their complications for support and self-esteem, British Journal of Social Psychology, 2004, 43.

Hobfoll S., Stres, kultura i społeczność. Psychologia i filozofia stresu, Gdańskie Wydawnictwo Psychologiczne, Gdańsk 2006.

Kirenko J., Wsparcie społeczne osób z niepetnosprawnością, Wydawnictwo WSUPiZ, Ryki 2002.

Kirenko J., Dylematy wsparcia społecznego osób z niepetnosprawnościa, [w:] Wsparcie społeczne w rehabilitacji i resocjalizacji, red. Z. Palak, Z. Bartkowicz, Wydawnictwo Uniwersytetu Marii Curie-Skłodowskiej, Lublin 2004.

Kirenko J., Sarzyńska E., Bezrobocie, niepetnosprawność, potrzeby, Wydawnictwo Uniwersytetu Marii Curie-Skłodowskiej, Lublin 2010.

Klamut R., Typy struktury sensu życia a treści celów wybieranych do realizacji, Roczniki Psychologiczne, 2012, 4(15).

Knoll N., Schwarzer R., Prawdziwych przyjaciót... Wsparcie społeczne, stres, choroba i śmierć, [w:] Wsparcie społeczne, stres i zdrowie, red. H. Sęk, R. Cieślak, Państwowe Wydawnictwo Naukowe, Warszawa 2005.

Konarska J., Poczucie sensu życia młodzieży z inwalidztwem wzroku, Wydawnictwo Uniwersytetu Marii Curie-Skłodowskiej, Lublin 1994.

Konieczna E.J., Poczucie sensu życia osób niepetnosprawnych ruchowo, Oficyna Wydawnicza Impuls, Kraków 2010.

Krok D., Religijny system znaczeń $i$ religijne radzenie sobie ze stresem a eudajmonistyczny dobrostan psychiczny, Roczniki Psychologiczne/Annales of Psychology, 2014, 17(4).

Lulek J., Głaz S., Problematyka sensu ludzkiego życia, [w:] Człowiek i jego życie religijne, red. S. Głaz, Wydawnictwo WAM, Kraków 2009.

Łaguna M., Lachowicz-Tabaczek K., Dzwonkowska I., Skala samooceny Morrisa Rosenberga - polska adaptacja metody, Psychologia Społeczna, 2007, 2.

Łuszczyńska A., Cieślak R., Protective, promotive and buffering effects of perceived social support in managerial stress: the moderating role of personality, Anxiety, Stress \& Coping: An International Journal, 2005, 18(3).

Majewicz P., Obraz samego siebie a zachowanie młodzieży niepetnoprawnej ruchowo, Wydawnictwo Naukowe Akademii Pedagogicznej, Kraków 2002.

Mądrzycki T., Osobowość jako system tworzacy i realizujacy plan - nowe podejście, Gdańskie Wydawnictwo Psychologiczne, Gdańsk 2002.

Michalski J., Konstruowanie tożsamości podmiotowej w kontekście kategorii sensu w pedagogice, Paedagogia Christiana, 2013, 2/32.

Moos R.H., Schaefer J.A., Coping resources and process: current concepts and measures, [w:] Handbook of stress: theoretical and clinical aspects, red. L. Goldberger, S. Breznits, The Free Press, New York 1993.

Necker J., Samowiedza i jej bohater, [w:] Poznaj samego siebie, czyli o źródłach samowiedzy, red. A. Niedźwieńska, J. Necker, Wydawnictwo WSPS, Warszawa 2009. 
Norris F.H., Kaniasty K., Received and perceived social support in times of stress: a test of the social support deterioration deterrence model, Journal of Personality and Social Psychology, 1996, 71(3).

Ogińska-Bulik N., Kaflik-Piróg M., Stres zawodowy w stużbach ratowniczych, Wydawnictwo WSHE, Łódź 2006.

Płużek Z., Osobowościowe uwarunkowania pytania o sens życia, [w:] Człowiek - wartości - sens, red. K. Popielski, Wydawnictwo KUL, Lublin 1996.

Popielski K.., Metody badań frustracji egzystencjalnej i nerwicy noogennej stosowane w logoterapii, Zdrowie Psychiczne, 1982, 1-2.

Popielski K., Noetyczny wymiar osobowości. Psychologiczna analiza poczucia sensu życia, Wydawnictwo KUL, Lublin 1994.

Popielski K., Psychologiczno-egzystencjalna interpretacja problematyki sensu i sensowności, [w:] Człowiek - wartość - sens, red. K. Popielski, Wydawnictwo KUL, Lublin 1996.

Poprawa R., Zasoby osobiste w radzeniu sobie ze stresem, [w:] Podstawy psychologii zdrowia, red. G. Dolińska-Zygmunt, Wydawnictwo Uniwersytetu Wrocławskiego, Wrocław 2001.

Rakowska A., Ksztatcenie akademickie a niepetnosprawność. Doświadczenia w pracy ze studentami, [w:] Student z niepetnosprawnościa w szkole wyższej, red. B. Tylewska-Nowak, W. Dykcik, Wydawnictwo Naukowe UAM, Poznań 2013.

Rorat M., Rola poczucia sensu życia w zmaganiu się z niepetnosprawnościa ruchowa, Student Niepełnosprawny. Szkice i Rozprawy, 2000, 4.

Rutkowska E., Wsparcie jako element rehabilitacji kompleksowej osób z niepetnosprawnościa, Niepełnosprawność - zagadnienia, problemy, rozwiązania, 2012, 3(4).

Schwarzer R., Knoll, N., Functional roles of social support within the stress and coping process: a theoretical and empirical overview, International Journal of Psychology, 2007, 42.

Sęk H., Wsparcie spoteczne jako kategoria zasobów i wieloznaczne funkcje wsparcia, [w:] Zasoby osobiste i społeczne sprzyjajace zdrowiu jednostki, red. Z. Juczyński, N. Ogińska-Bulik, Wydawnictwo Uniwersytetu Łódzkiego, Łódź 2003.

Sęk H., Cieślak R., Wsparcie społeczne - sposoby definiowania, rodzaje i źródła wsparcia, wybrane koncepcje teoretyczne, [w:] Wsparcie społeczne, stres i zdrowie, red. H. Sęk, R. Cieślak, Państwowe Wydawnictwo Naukowe, Warszawa 2005.

Steger M.F., Meaning in life, [w:] The Oxford handbook of positive psychology, red. S.J. Lopez, C.R. Snyder, Oxford University Press, Oxford 2011.

Steger M.F., Oishi S., Kashdan T.B., Meaning in life across the life span: levels and correlates of meaning in life from emerging adulthood to older adulthood, The Journal of Positive Psychology, 2009, 4(1).

Steuden S., Okła W., Czynniki sprzyjające podnoszeniu jakości życia w sytuacji choroby, [w:] Jakość życia w chorobie, red. S. Steuden, W. Okła, Wydawnictwo KUL, Lublin 2006.

Strelau J., Psychologia różnic indywidualnych, Wydawnictwo Naukowe Scholar, Warszawa 2006.

Teusz G., Znaczenie wsparcia społecznego w doświadczaniu przez młodzież krytycznych wydarzeń życiowych, Auxilium Sociale, 2005, 3-4.

Warr P., Psychologiczne skutki długotrwałego bezrobocia, [w:] Człowiek w społecznej przestrzeni bezrobocia, red. T. Chirkowska-Smolak, A. Chudzicka, Wydawnictwo Naukowe UAM, Poznań 2004.

Waters L.E., Moore K.A., Predicting self-esteem during unemployment: the effect of gender, financial deprivation, alternate roles and social support, Journal of Employment Counseling, 2002, 39. 
Watson D., Suls J., Haig J., Global self-esteem in relation to structural models of personality and affectivity, Journal of Personality and Social Psychology, 2002, 83.

Zaborowski Z., Świadomość i samoświadomość człowieka, Wydawnictwo Psychologii i Kultury Enetela, Warszawa 1998. 